\title{
DCLRE1A Gene
}

National Cancer Institute

\section{Source}

National Cancer Institute. DCLRE1A Gene. NCI Thesaurus. Code C106142.

This gene plays a role in both DNA repair and the cell cycle. 